Please do not remove this page

RMIT

UNIVERSITY

\title{
Screening for potential effects of endocrine-disrupting chemicals in peri-urban creeks and rivers in Melbourne, Australia using mosquitofish and recombinant receptor-reporter gene assays
}

Chinathamby, Kavitha; Allinson, Mayumi; Shiraishi, Fujio; Lopata, Andreas; Nugegoda, Dayanthi; Pettigrove, Vincent; Allinson, Graeme

https://researchrepository.rmit.edu.au/esploro/outputs/9921859234301341/filesAndLinks?institution=61RMIT_INST\&index=null

Chinathamby, K., Allinson, M., Shiraishi, F., Lopata, A., Nugegoda, D., Pettigrove, V., \& Allinson, G. (2012). Screening for potential effects of endocrine-disrupting chemicals in peri-urban creeks and rivers in Melbourne, Australia using mosquitofish and recombinant receptor-reporter gene assays. Environmental Science and Pollution Research, 20(3), 1831-1841. https://doi.org/10.1007/s11356-012-1188-2 Document Version: Accepted Manuscript

Published Version: https://doi.org/10.1007/s11356-012-1188-2

Repository homepage: https://researchrepository.rmit.edu.au (c) Springer-Verlag 2012

Downloaded On 2023/04/26 20:37:02 +1000 
Thank you for downloading this document from the RMIT Research Repository.

The RMIT Research Repository is an open access database showcasing the research outputs of RMIT University researchers.

RMIT Research Repository: http://researchbank.rmit.edu.au/

\section{Citation:}

Chinathamby, K, Allinson, M, Shiraishi, F, Lopata, A, Nugegoda, D, Pettigrove, V and Allinson, G 2012, 'Screening for potential effects of endocrine-disrupting chemicals in peri-urban creeks and rivers in Melbourne, Australia using mosquitofish and recombinant receptor-reporter gene assays', Environmental Science and Pollution Research, vol. 20, no. 3, pp. 1831-1841.

See this record in the RMIT Research Repository at:

https://researchbank.rmit.edu.au/view/rmit:20765

Version: Accepted Manuscript

Copyright Statement: (C) Springer-Verlag 2012

Link to Published Version:

http://dx.doi.org/10.1007/s11356-012-1188-2 


\section{Author Copy}

This document is the Author's personal copy of the article published in September 2012:

Chinathamby K, Allinson M, Shiraishi F, Lopata AL, Nugegoda D, Pettigrove V, Allinson G (2013). Screening for the potential effects of endocrine disrupting chemicals in peri-urban creeks and rivers in Melbourne, Australia using mosquitofish and recombinant receptorreporter gene assays. Environmental Science and Pollution Research 20(3): 1831-1841. DOI 10.1007/s11356-012-1188-2.

The original publication is available at: http://link.springer.com/article/10.1007/s11356-012$\underline{1188-2}$

The Author does not make any representation that the contents of this Author copy are complete or accurate or up to date compared to the published article.

This article may be used for research, teaching, and private study purposes. Any substantial or systematic reproduction, redistribution, reselling, loan, sub-licensing, systematic supply, or distribution in any form to anyone is expressly forbidden.

The Authors shall not be liable for any loss, actions, claims, proceedings, demand, or costs or damages whatsoever or howsoever caused arising directly or indirectly in connection with or arising out of the use of this material. 
Screening for the potential effects of endocrine disrupting chemicals in peri-urban creeks and rivers in Melbourne, Australia using mosquitofish and recombinant receptor-reporter gene assays

Kavitha Chinathamby ${ }^{1,2}$, Mayumi Allinson ${ }^{2}$, Fujio Shiraishi ${ }^{3}$, Andreas L. Lopata, ${ }^{1,4}$

Dayanthi Nugegoda $^{1,2}$, Vincent Pettigrove ${ }^{2,5}$, Graeme Allinson ${ }^{2,6}$

1 School of Applied Sciences, RMIT University Bundoora West Campus, GPO Box 71, Bundoora 3083, Australia

2 Centre for Aquatic Pollution Identification and Management (CAPIM), The University of Melbourne, Bio21 Institute, 30 Flemington Road, Parkville, Victoria 3010 Australia

3 Environmental Quality Measurement Section, Research Centre for Environmental Risk, National Institute for Environmental Studies, 16-2 Onogawa, Tsukuba, Ibaraki 305-8506, Japan

4 School of Pharmacy and Molecular Science, James Cook University, Townville, Queensland 4811, Australia

5 Melbourne Water Research and Technology, Melbourne Water Corporation, PO Box 4342, VIC 3000, Australia

6 Future Farming Systems Research, Department of Primary Industries, DPI Queenscliff Centre, Queenscliff, Victoria 3225, Australia 


\section{Address for correspondence}

Dr Graeme Allinson

Future Farming Systems Research,

Department of Primary Industries Queenscliff Centre,

Queenscliff, Victoria 3225, Australia

Tel: +61 352580111

Fax: +61 352580270

Email: graeme.allinson@dpi.vic.gov.au 


\section{Abstract}

Sexually mature male mosquitofish (Gambusia holbrooki) were collected from various sites around Melbourne in 2009 to evaluate the performance of gonopodial indices as a biomarker for endocrine disruption in Melbourne's waterways. The mosquitofish indices assessed were body length, gonopodial length/body length ratio, ray 4: 6 ratio, and the absence or presence of hooks and serrae, and these varied between sites. The study was complemented by measurements of the estrogenic, retinoid, thyroid and aryl hydrocarbon receptor activity of the water. Male mosquitofish were 16.3 - $21.5 \mathrm{~mm}$ in length, and, although there was a statistically significant positive relationship showing that bigger fish had longer gonopodia than small fish $\left(r^{2}=0.52, p^{<} 0.001\right)$, there were few significant differences in GL/BL ratio of fish between sites. Measured estrogenic activity was mostly in the range $0.1-1.7 \mathrm{ng} / \mathrm{L} \mathrm{EEQ}$, with one site having much higher levels ( 12 ng/L EEQ). Aryl hydrocarbon receptor activity was observed in all water samples (7-180 ng/L $\beta$ NF EQ), although there was no consistent pattern in the level of AhR activity observed, i.e. 'clean’ sites were as likely to return a high AhR activity response as urban or WWTP impacted sites. There was no correlation between measurements of receptor actvity and gonopodium length: body length ratio and body length. We conclude that the mosquitofish gonopodia only fulfills part of the criteria for biomarker selection for screening. The mosquitofish indices assessed were cheap and easy to perform procedures, however there is no baseline data from the selected sites to evaluate whether differences in the morpholical indices observed at a site were a result of natural selection in the population or due to estrogenic exposure. 
Keywords

Male mosquitofish, gonopodium, two-hybrid yeast recombinant receptor-reporter gene assay activity, Australia 


\section{Introduction}

In the late 1990s, Jobling et al. (1998) reported an unusually high incidence of intersex in wild populations of the roach (Rutilus rutilus) in English rivers. This was arguably the first welldocumented example of a widespread sexual disruption in wild populations of aquatic vertebrates, with the reproductive abnormalities being broadly consistent with exposure to hormonally active substances associated with discharges from municipal wastewater treatment plants (WWTPs). Since then, although the occurrence of endocrine disrupting chemicals (EDCs) in WWTP discharges and their impacts on aquatic wildlife have generated a significant amount of scientific and public interest, there has been little relevant Australian information produced. Selecting a suitable fish species for environmental monitoring in Australia can be limited by scientific factors, such as the abundance and spatial distribution of a species, and social factors, such as limitations placed on collection of native fish by institutional animal ethics committees. For such pragmatic reasons, the introduced and ubiquitous mosquitofish, Gambusia holbrooki, has been suggested as a candidate species for screening for the effects of endocrine disrupting chemicals in peri-urban creeks and rivers in Australia.

The mosquitofish (Gambusia holbrooki) is a small, short lived, sexually dimorphic species introduced into Australia in 1925 as biological control to curb mosquito populations (Morgan et al. 2004; Ayres et al. 2010). Now considered a noxious species, the mosquitofish is commonly found in freshwater streams and creeks in Victoria, where it inhabits shallow, still or slow moving reasonably vegetated water in a wide range of environments from apparently pristine creeks to highly disturbed urban environments (Pyke 2008). Both the eastern and western mosquitofish show a preference for warmer water temperatures between $25^{\circ} \mathrm{C}$ and $31^{\circ} \mathrm{C}$ (Winkler 1979; Lada et al. 2006). Although aggressive in behaviour, mosquitofish often 
move around in groups locally in a small area (Pyke 2005). Male mosquitofish are typically much smaller than females.

Born with undifferentiated anal fins (gonopodia) which elongate during development, male mosquitofish use their gonopodia during copulation to transfer sperm into the female (Angus et al. 2001). In juvenile mosquitofish, anal fin ray numbers 3 through 6 are not different in either sex. However, in mature adult males, rays 3, 4 and 5 elongate progressively until they are twice as long as the other rays in the fin. Angus et al. (2001) reported that the ratio of the length of rays 4 and 6 is an average of 2.5 times for a normal adult male mosquitofish (see Figure 1). The fully developed gonopodium also has a number of serrae and hooks at the tip which help the male secure the female during copulation. Gonopodial development normally takes between 30 to 50 days to complete, and, because its development is androgen dependant fin growth and ray ratios can be inhibited by exposure to estrogenic chemicals (Angus et al. 2005; Doyle and Lim 2002). In the wild, estrogenic effects on mosquitofish gonopodial morphology have been suggested by Batty and Lim (1999), Toft et al. (2003) and Game et al. (2006). In the laboratory, modifications to the gonopodial length have been observed when juvenile male fish were exposed to estrogenic chemicals (Dreze and Monad 2000; Doyle and Lim 2002; Angus et al. 2005), however, once the gonopodium is fully developed, exposure to estrogenic compounds does not seem to have an effect on the fish. These hormone-dependant morphologic attributes have, in part, led to the mosquitofish being a valuable candidate biomonitor for endocrine disruptors (Hou et al 2011; Norris and Burgin 2011, Xie et al 2010).

The wide structural variety of EDCs for the most part restricts the applicability of singlecompound chemical analysis of complex matrices, such as found in many peri-urban waterways. Several in vitro assays have been developed to screen the hormonal activity of 
compounds in natural waters, including ligand-binding assays, recombinant receptor-reporter gene assays, assays based on the measurement of cell proliferation, and enzyme-linked immunosorbent assays (ELISA; Streck 2009; Kinnberg 2003). Recombinant receptor-reporter gene assays, such as the yeast two-hybrid bioassays used in this study, measure the activation of receptor, and allow for quantification of hormonal activity, without having to know the precise chemical make up of the sample. They have, however, been little utilised on natural water samples in Australia, with the only Victorian information published to date that of Allinson et al (2011a) who reported negligible estrogenic (ER), retinoid (RAR) and thyroid (TR) receptor activity, but measurable aryl hydrocarbon (AhR) receptor activity in the main stem of the Yarra River Victoria.

In recognition of the potential risks that EDCs pose to aquatic ecosystems, and the lack of robust information on the levels of such compounds in Victorian freshwaters, this study was initiated to assess the gonopodia of mosquitofish as a suitable biomarker of effect for estrogenic contamination. To that end, Gambusia holbrooki were collected from 16 urban, periurban and rural waters around Melbourne between February 9 and April 1, 2009. One of the challenges in environmental monitoring is the lack of a combined approach using chemical measurements of contaminants and bioanalytical tools to investigate health of ecosystems as a parallel study (Sumpter and Johnson 2008). To address this challenge, grab water samples were obtained from the sites, and samples prepared for a number of bioanalytical tests, including measurement of sample 'hormonal' activity using human and medaka (Oryzias latipes) estrogen (hER $\alpha$ and medER $\alpha$ ), retinoic acid (RAR), aryl hydrocarbon (AhR), and thyroid (TR) receptor assay activity using a suite of yeast-based bioassays. The two sampling approaches were used to identify sites that may be most impacted by endocrine disrupting chemicals. 


\section{Materials and Methods}

Study sites

Sexually mature adult male mosquitofish with elongated gonopodia (see Figure 1) were collected using a dip net from streams, lakes and wetlands in and around Melbourne (Figure 2) between February 9 and April 1, 2009; streams were grouped according to surrounding land use types such urban (U), rural (R) wastewater treatment plant impacted (WWTP) and reference sites (Ref), although in some case this grouping is somewhat arbitrary since some creeks flow through both residential and industrial or agricultural land and may contain a combined source of pollutants. In the field, fish were euthanized (blow to the head), transported on ice to the RMIT Ecotoxicology Laboratory and stored in $70 \%$ ethanol for later morphometric measurements.

Fish morphometrics

Body length was measured using a caliper to the nearest $0.01 \mathrm{~mm}$ from snout to caudal peduncle. Gonopodial length (GL) defined as the length from the anterior base of the anal fin to the gonopodial tip was measured under a Wild M3Z Heerbrugg stereozoom microscope using an objective micrometer to the nearest $0.01 \mathrm{~mm}$. The length of rays 4 and 6 were also taken as a measure of the elongation index of the ratio of rays 4:6 (R4:6). The presence and absence of hooks and serrae at the tip of the gonopodia indicate maturity and was also noted. Fish deemed immature were not used in the study. Fish whole bodies were weighed to the nearest $0.001 \mathrm{mg}$; because the liver and gonads were removed for other measurements (data not reported), the eviscerated mass reported. Dependent variables included standard body lengths (SBL), gonopodium length : body length ratio (GL/BL), elongation ratio (R4:6) and body mass. 
Water sampling

Water samples were collected as 'grab’ or spot samples from the16 urban, peri-urban and rural waters (Figure 2). Samples were directly collected in glass bottles, stored on ice, and then at $4^{\circ} \mathrm{C}$ until processed (generally within $36 \mathrm{~h}$ of collection). For each site, an aliquot of the effluent (1L) was extracted for the measurement of receptor (hormonal) activity using a yeastbased bioassay. The sample preparation methods for these tests are described elsewhere (Shiraishi et al. 2000; Allinson et al. 2007, 2008), but, in short, involved filtration and adding buffer solution to the sample to ensure an acid pH (according to JEA 1998), filtration through GF/C filters to remove particulate matter, and then solid phase extraction (for bioassays: SPE; Octadecyl C18 disk (Empore; $47 \mathrm{~mm}$; 3M, MN, USA); for ELISA: Discovery DSC-18 cartridge (6 mL $500 \mathrm{mg}$, Supelco, PA USA)). After elution of analytes with methanol and evaporation, the sample was re-suspended in a mixture of 3:1 hexane: dichloromethane $(1 \mathrm{~mL})$, and loaded onto a florisil column (Varian Bond Elut-FL, $500 \mathrm{mg}$, 3mL; CA, USA). For all samples, elution protocols separated the extract into three fractions, first a 3:1 hexane:dichloromethane fraction (H/D), second a 1:9 acetone:dicholoromethane fraction (A/D), and finally a methanol fraction $(\mathrm{MeOH})$. The $\mathrm{A} / \mathrm{D}$ fraction contained the steroid hormones, and the separation was undertaken to minimise the effects of matrix components on the ELISA and bioassay systems.

Measurement of estrogenic and retinoic acid activity was undertaken with a yeast two-hybrid recombinant receptor-reporter gene bioassay system in accordance with the method of Shiraishi et al. 2000 (described in English in Allinson et al. 2008) using yeast cells (Saccharomyces cerevisiae Y190) into which the human estrogen receptor $\mathrm{ER} \alpha$ or the estrogen receptor from 
Japanese medaka (Oryzias latipes) had been inserted (hER $\alpha$ and medER $\alpha$, respectively; Nishikawa et al. 1999), and the method of Kamata et al. (2008) using the same strain of yeast into which the human RAR $\gamma$ receptor had been inserted. Measurement of AhR activity was undertaken in accordance with the method of Kamata et al. (2009) using yeast cells (YCM3) carrying the response element for the AhR complex, XRE5 (Miller 1999). Measurement of TR activity was undertaken according to Shiraishi et al. (2003). Positive controls were used with all assays: hER $\alpha$ and medER $\alpha$ assays, 17 $\beta$-estradiol and estrone (Wako Pure Chemical Industries Ltd, Osaka, Japan); RAR assay, all-trans-retinoic acid (a-t-RA; Wako Pure Chemical Industries Ltd, Osaka, Japan); AhR, $\beta$-naphthoflavone ( $\beta$ NF; Wako Pure Chemical Industries Ltd, Osaka, Japan); and TR, triiodothyronine (T3; Wako Pure Chemical Industries Ltd, Osaka, Japan). A solvent (vehicle) control (DMSO, Nacalai Tesque Inc., Kyoto, Japan) was used in all cases. The agonist activities of the H/D, A/D and $\mathrm{MeOH}$ fractions of the sample extracts were measured, and unless otherwise stated data is reported as the sum of the activity observed in all three fractions. The bioassay method's limits of reporting (LOR) for the hER $\alpha$ and medER $\alpha$ systems were 0.1 and $0.4 \mathrm{ng} / \mathrm{L} 17 \beta$-estradiol equivalents (EEQ), respectively. For the RAR, AhR, and TR bioassays, they were 0.4 ng/L a-t-RAEQ, 0.4 ng/L $\beta N F E Q$, and 10 ng/L T3EQ, respectively.

Measurement of total estrogens (ES) was undertaken using commercial ELISA kits in accordance with the manufacturer's instructions (Ecologiena ${ }^{\circledR}$ Estrogenes (E1/E2/E3) ELISA Kit (Tokiwa Chemical Industries, Japan)). In order to verify calibration accuracy, check standards (i.e. standards from the kit run as samples) were run in duplicate on each ELISA plate during each ELISA test. The ratio of nominal concentrations and result values were $105 \%$ for total estrogen. The ELISA kit manufacturer claims that the ES monoclonal antibody binds 
"exclusively with E1, E2, and estriol (E3) and does not show cross-reaction with other chemicals of similar structures.” Consequently, to assess the relative response of the ELISA kit, the kits were challenged with E1, E3, and both $17 \alpha$ - and $17 \beta$-E2. The average ratio of nominal concentrations and result values were: E1, 70\%; E3, 50\%; 17 $\alpha-\mathrm{E} 2,10 \% ; 17 \beta-\mathrm{E} 2,100 \%$. The ELISA method LOR was $0.1 \mathrm{ng} / \mathrm{L}$ EEQ.

\section{Statistical analysis}

All statistical analyses were performed using PASW ver. 18.0 for Macintosh. Significance was set at $\alpha=0.05$ for all tests. For statistical comparisons each measurement data was tested for normality and homoscedasity. If data met assumptions of heterogeneity and normality required for parametric methodologies, one-way analysis of variance (ANOVA) was used to test for differences between sites; else the data was transformed before testing. Specifically, body length was log transformed, whereas gonopodium length: body length ratio was arcsin transformed before testing. A post hoc Dunnet's test was used to identify differences between means. Pearson's correlation coefficient was used to test for differences between total estrogenic levels and mean gonopodium length: body length ratio and mean body lengths at the collection sites. Data for measured biological endpoints are presented as mean \pm standard error.

\section{Results and Discussion}

The factors that influence the size at which male mosquitofish reach sexual maturity are somewhat varied. A number of studies have reported that mosquitofish size and gonopodial indices are influenced by factors such as population density and the social environment as well as environmental factors such as temperature. For instance, Meffe (1992) demonstrated that 
mosquitofish grew faster and larger at $25^{\circ} \mathrm{C}$ than at $32^{\circ} \mathrm{C}$; Site 11 (a reservoir) had the highest temperature (at $25^{\circ} \mathrm{C}$ ) and also significantly larger fish compared to all other sites (Table 1). Zulian et al. (1995) found that the mean size of mature males is dependent on population density, with males attaining larger sizes and maturing later in high density populations, and that small size is favoured in populations with female-biased sex ratios or low density (Zulian et al. 1995). Bisazza and Marin (1995) found that small males take less time to mature sexually. Maturing faster lengthens reproductive life and reduces mortality before reproduction. In this study, the mean size of male mosquitofish ranged from $16.3 \mathrm{~mm}$ at Site 1 (U) to 21.5 $\mathrm{mm}$ at Site 11 (Ref); the latter were significantly larger than fish from all other sites $(\mathrm{P}<0.01)$ (Table 1). Fish from Site 1 (U) were significantly smaller than fish from Sites 11 (Ref), 8 (WWTP), 15 (R), 2 (U), and 3 (U) (P < 0.01). Fish from Site 11 (Ref) also had the largest body mass compared to fish from all sites except from five rural sites (Sites 14, 15, and 16), and two urban sites (Sites 2 and 3) $(\mathrm{P}<0.05)$. The variation in body size among sites in this study can be attributed to mosquitofish exhibiting natural developmental plasticity to take advantage of varying environmental conditions (Zulian et al. 1993).

Gonopodial length:body length ratio (GL/BL)

There was a positive and statistically significant relationship showing that bigger fish had longer gonopodia than small fish $\left(r^{2}=0.52, \mathrm{p}<0.001\right)$. There were no significant differences in GL/BL ratio of fish when comparing all the reference sites to the WWTP sites with one exception; fish from Site 5 (WWTP) had a significantly larger GL/BL ratio compared to fish from Sites 11 (Ref), 2 (U) and $3(\mathrm{U})(\mathrm{P}<0.05)$. The only significant difference in R4:6 ratio observed was between fish from Site 5 (WWTP) and Site $15(\mathrm{R})(\mathrm{P}<0.05)$. This trait provides a more accurate measure of elongation in that Ray 6 does not elongate while Ray 4 lengthens 
during gonopodial development (Angus et al. 2001), and therefore is not being subjected to allometry (Angus et al. 2005).

The elongation of rays 3,4 and 5 of the mosquitofish gonopodium are androgen dependent and their outgrowths have been induced in juvenile males with the administration of the androgens ethynl testosterone (Ogino et al 2004) and 17 $\beta$-trenbolone (Sone et al 2005). In that context, Angus et al (2001) demonstrated an increase in R4:6 ratio in fins of female mosquitofish exposed to 11-ketotestosterone for 77 days. A similar androgenic response in both male and female mosquitofish exposed to paper mill effluents showed a significant increase in segments of ray 3, which also elongates, like ray 4 in male fish (Hou et al 2011). Angus et al. (2001) reported that $\mathrm{R} 4: 6$ ratio averages 2.5 . In this study, the highest mean R4:6 ratio observed in fish from Site 5 (2.86, WWTP) even though these fish were some of the smallest in size, perhaps suggesting that fish from this site may have been exposed to androgenic pollutants. Moreover, the data from Site 5 is similar to results reported by both Angus et al (2002) and Leusch et al. (2006) where fish captured downstream of a treatment plant had longer gonopodia.

Many of the hormonally active chemicals found in contaminated waters are also directly toxic to aquatic organisms, and may affect the bioassays used in this study. Unfortunately, we were unable to assess toxicity or genotoxicity of the water samples collected during fish surveys, so we cannot evaluate the potential impact of known point-sources, land-use or in some cases, the bush-fires that raged through the upper Yarra catchment in the summer of 2009, on the performance of the bioassays (Table 2). However, the results of the positive controls run at the same time as the samples suggest the bioassays were performing to expectation, and thus capable of measuring low ng/L levels of hormonal activity. In that context, on the whole low levels of estrogenic activity were observed was low using the yeast-based bioassay (generally 
below 2 ng/L, with the exception of Site 7, $12.0 \mathrm{ng} / \mathrm{L}$ EEQ; Table 2). A similar pattern was observed using ELISA. Consequently, lack of any observed bioassay response is most likely due to lack of receptor-inducing compounds in the samples, rather than a toxic effect on the yeast cells. Estrogenic activity was observed at all four WWTP effluent impacted sites, but only sporadically in the reference, rural and urban sites (Table 2). Specifically, reference sites (in the order lowest to highest ES, sites 11, 12, 9 and 10) had, for the most part lower ES than rural sites (Sites 13, 14, 16, 15 and 4). ES at rural sites was not noticeably different from that observed at the urban sites (Sites 1, 2, and 3) or the majority of the WWTP sites (Sites 5, 6 and 8). The one stand-out site was Site 7 (ES, $12.5 \mathrm{ng} / \mathrm{L} \mathrm{EEQ).} \mathrm{There} \mathrm{was} \mathrm{a} \mathrm{very} \mathrm{good} \mathrm{correlation}$ between estrogenic activity and the measured total estrogen concentrations for these freshwater samples for both the hER $\alpha \square$ bioassay ( $\left.r^{2}=0.98\right)$, and the medER $\alpha$ bioassay $\left(r^{2}=0.97\right.$; Allinson et al. 2011b).

The low estrogen agonist activity observed in this study is broadly comparable with many international reports. For instance, Inoue et al. (2009) reported less than 0.3 ng/L EEQ in six rivers of central Japan; Jugan et al. (2009) observed higher estrogenic activity in the River Seine downstream of two WWTP discharge points compared to upstream control sites (up to 2.5 cf. < 1.2 ng/L EEQ, respectively); Schilirò et al. (2009) reported that the estrogenic activity was $5.0 \pm 6.1 \mathrm{ng} / \mathrm{L}$ EEQ upstream of a WWTP on the Dora Riparia River (one of the tributaries of the River Po) in north-west Italy, but that estrogenic activity did not increase downstream of the WWTP (6.7 $\pm 7.4 \mathrm{ng} / \mathrm{L} \mathrm{EEQ);} \mathrm{and} \mathrm{Lavada} \mathrm{et} \mathrm{al.} \mathrm{(2009)} \mathrm{who} \mathrm{examined} \mathrm{estrogenic} \mathrm{activity}$ in agricultural and peri-urban rivers in California, reporting that most sites had low $(<10 \mathrm{ng} / \mathrm{L}$ EEQ) activity but that the highest in vitro bioassay responses were mot consistently observed at sites associated with agriculture on the Sacramento, Tuolumne and Merced rivers $(<0.15-164$; 24.6-242; and <0.15-56.1 ng/L EEQ respectively; Table 3). 
There was no correlation observed between the physiological indices used in this study and measured levels of estrogen receptor activity, despite the estrogenic activity observed at some of the sites in principle being capable of inducing effects in fish (e.g. $0.2-2$ ng/L EEQ; Burkhardt-Holm et al. 2008). We do, however, need to be somewhat cautious in making this conclusion. First, the yeast-based recombinant receptor-reporter gene assays used in this study provide an indication of external exposure to estrogenic compounds through an integrated measure of estrogenic activity in the water. This may not reflect internal exposure, and since it is the internal exposure at the site(s) of action that drives a response in the gonopodium biomarker, the lack of any correlation between observed gonopodial responses and bioassayderived estrogenic activity in the water may simply reflect the difference between external and internal estrogenic exposure. One of the challenges in environmental monitoring is the lack of a combined approach using chemical measurements of contaminants and bioanalytical tools to investigate health of organisms as a parallel study (Sumpter and Johnson, 2008). So, in this study, grab water samples were obtained from the mosquitofish sites at the time of fish sampling and measurements of estrogenic activity made. However, for the effects of estrogens to be observable via the gonapodial biomarker, juvenile male fish would have had to be exposed to estrogenic pollutants during development as once developed the gonopodia will not be affected (Angus et al. 2005), and so again we must be cautious in using the exposure 'snapshots' provided by the grab water sampling when trying to correlate the physiological indices used in this study with measured levels of estrogen receptor activity, because of the potential for temporal variation in estrogen concentrations. However, the current world wide consensus is that natural steroid estrogens usually provide the majority of the estrogenic activity rivers, with a range of anthropogenic chemicals being the dominant in certain specific locations (Sumpter and Johnson, 2008). Natural steroid estrogens, tend to be continually 
discharged into rivers rather than being one-off occasional events. Although easily degraded in river water (with half-lives of around a few days), and with limited evidence of reservoireffects resulting from sorption to organic materials in sediment, the natural steroidal estrogens are 'pseudo-persistent,' a concept that was conceptualised by Sumpter and Johnson (2008) as, “a perpetual plume, whose dimensions are modified by dilution, but remain ... like an 'eternal flame'.” In that context, the yeast assay and ELISA measurements of total estrogenic activity in the grab water samples provide a reasonable estimate of the background exposure to estrogens in the sampled rivers. However, to more fully address this challenge, there is a need to monitor estrogenic, and other hormonal activities, at sampling sites for several months prior to sampling the fish in conjunction with an internal biomarker of exposure, such as VTG expression.

Retinoid activity (<0.4 - 8.1 a-t-RA EQ; Table 2) was observed at most clean and rural sites, but only half of the WWTP effluent impacted and one urban site. There were no consistent patterns in the level of retinoid activity observed, i.e. the reference sites were as likely to return a high RAR activity response as urban or WWTP impacted sites. There are few studies with which to compare our results, but the data is consistent with that Gardiner et al. (2003) who reported RAR agonistic activity in lake and pond water samples from Minnesota and California, respectively, where frog malformations were routinely found; and that of the RAR agonist activity reported by Inoue et al. (2010) in samples collected from 20 sites on the Ina and Lake Biwa-Yodo Rivers in central Japan (1.1 to 23.5 ng/L atRA EQ). Vitamin A (retinol) and its biologically active metabolites (collectively known as retinoids) play an important role in the development and maintenance of vertebrates, including being necessary for visual development, control of growth, and differentiation of embryonic cells (Inoue et al. 2010; Janośek et al. 2006, 2008). Although the precise mechanisms by which retinoid signalling 
pathways are disrupted by xenobiotic chemicals are not understood, it is well known that both a deficiency and a surplus of endogenous retinoids, most notably retinoic acids (RAs), can cause physiological impacts. The highest RAR agonistic activity was $8.1 \mathrm{ng} / \mathrm{L}$, which is two orders of magnitude lower than the a-t-RA concentration reported to cause RAR-mediated adverse effects (dysmorphogenesis of embryonic structures) in Xenopus laevis (0.6 $\mu \mathrm{g} / \mathrm{L}$; Degitz et al. 2003), although this does not mean that negative effects by the putative environmental retinoids are not occurring in the freshwater environment we targeted.

None of the samples produced a positive response on the TR assay, which is consistent with Jugan et al. (2009) who reported no TR agonist activity in river water extract at sites on Seine River upstream of any WWTP influence, and Inoue et al. (2009) who reported minimal TR activity in six rivers of central Japan except at two sites downstream of WWTPs.

Aryl hydrocarbon receptor activity was observed in all water samples (7 - 180 ßNF EQ; Table 2), although again there was no consistent pattern in the level of AhR activity observed, i.e. the ‘clean' reference sites were as likely to return a high AhR activity response as urban or WWTP impacted sites (Table 2). Bioassays based on the binding to the AhR have previously been used only once for the evaluation of contamination of peri-urban waters in Victoria (Allinson et al 2011a) who reported a progressive increase in AhR agonist activity upstream-downstream in the main stem of the Yarra River (10 - $27 \mathrm{ng} / \mathrm{L} \beta$-NF EQ). It is, however, difficult to compare our results directly with the few other studies reporting AhR activity in river waters, because of differences in bioassay systems incubation protocols, cellular type (e.g. yeast cells cf. human cell lines), expression of response (e.g. chemiluminescence cf. luciferase expression) and reporting units (e.g. $\beta N F$ equivalents cf. TCDD equivalents). However, with respect to the latter, Kamata et al. (2009) has suggested that the AhR affinity of $\beta N F$ is about the same as that 
of TCDD in the YCM3 cell assay, especially at the relatively low concentrations that are significant for data analysis in this assay. Therefore, the numerical activities of the 16 river waters samples relative to TCDD are roughly the same as reported for $\beta$ NF. Consequently, even though TCDD EQ activity was not assessed directly (for laboratory safety reasons), we are able to say that this study's results are higher than those of Rawson et al. (2009), who observed up to $0.032 \mathrm{ng} / \mathrm{L}$ TCDDEQ in water samples from 10 wetlands and 24 creeks and rivers in Sydney using the H4IIE bioassay. Moreover, if we assume that the AhR agonist behaviour of all the AhR ligands in our samples is additive and can be represented by the effects of 2,3,7,8-TCDD, the observed AhR activity (7-180 ng/L $\beta \mathrm{NF}$ EQ) would represent concentrations of 2,3,7,8-TCDD that would be at least one order of magnitude lower than those reported to cause jaw malformation in zebra fish embryos via AhR-mediated down-regulation of the chondrogenic transcription factor, sox9b (Xiong et al., 2008; $1 \mu \mathrm{g} / \mathrm{L}$ ).

Although there is considerable understanding that many chemicals act as agonists at the estrogenic receptor, there is much less understanding of the impact of anti-estrogenic chemicals, i.e. compounds that antagonize or inhibit estrogen-dependent processes, and of cross-talk between receptor mediated cellular functions (Sumpter 2008; Kirby et al, 2007; Navas and Segner 2000). The majority of known AhR ligands are coplanar aromatic dioxinlike compounds. For instance, Hilscherová et al. (2000) reported that the three potential classes of compounds with dioxin-like properties that can bind to the AhR were (1) planar hydrophobic aromatic compounds (such as planar congeners of PCBs and PCDD/PCDFs, polychlorinated naphthalenes (PCNs), and several high molecular weight PAHs); (2) poly- and mixed halogenated and alkylated analogues of class (1) compounds, chlorinated xanthenes and xanthones, and polychlorinated diphenyl toluenes, anisols, anthracenes, fluorenes); and (3) a wide range of non-planar, non-aromatic, lipophilic compounds that are transient inducers and 
weak AhR ligands (includes natural compounds like indoles, heterocyclic amines, and some pesticides and drugs). In that context, a number of coplanar aromatic compounds are known to bind to the AhR, induce the biotransformation enzyme cytochrome P450 1A (CYP 1A), and cause anti-estrogenic effects, such as reduced vitellogenin (VTG) synthesis or impaired gonad development (Navas and Segner 2000). CYP1A1 is the terminus of the mixed function oxygenase (MFO) system and plays a key role in the detoxification of contaminants such as PAHs. In this study, there was no evidence of any correlation between the physiological indices used and measured levels of AhR receptor activity, but it is possible that PAHs from known point-sources, land-use or in some cases, the bush-fires that raged through the upper Yarra catchment in the summer of 2009, may have affected the physiological indices through antiestrogenic mechanisms mediated through the AhR. Further research on the extent to which the ER and AhR systems can influence each other in the development of mosquitofish when both are being stimulated - so-called 'crosstalk' - is required.

Biomarkers are often considered as early warning systems (den Besten 1998; Hanson 2009), although the usefulness of the selected biomarker to trigger further research depends on the suitability of the biomarker. Van der Oost et al. (2003) states that a biomarker should be reliable, relatively cheap, easy to perform, and sensitive to pollution exposure/effects. Baseline data should be available to determine that the effect is pollution induced and not due to natural variability. For screening purposes, the gonopodium of the male mosquitofish was selected as a cost effective and simple biomarker to detect the effects of estrogenic contaminants. Measuring mosquitofish gonopodia is cheap and easy to perform with a microscope. Mosquitofish are ubiquitous and have been used as a bioindicator organism for different types of contaminants in many studies all around the world. However, the data obtained in our study is inconclusive and 
suggests that the selected mosquitofish indices may be influenced by natural variability and other environmental factors. 


\section{Conclusions}

In the laboratory, the investigation of changes in the male mosquitofish gonopodium appears to be a sensitive morphological biomarker of estrogenic exposure if exposure occurs during the period of sexual maturation for male fish. However, this does not appear to be the case in the field, where mosquitofish are highly plastic and adaptable to a variety of water conditions making interpretations of morphological characteristics complicated. Confounding factors such as temperature, individual site history, predators and other factors may have influenced indices selected for this study. The estrogenic activities observed in water samples at some of the sites are capable of inducing effects in fish, however no correlations with morphological effects were observed in this study. It is recommended that baseline data be obtained from a range of relevant field sites to better understand natural variability in the gonopodia of the mosquitofish in order for it to be used as a reliable biomarker in Australian conditions. It is also recommended that a multi-assessment method using various biomarkers be used to evaluate estrogenic and other receptor effects in contaminated waters, i.e combining external measurements of chemical exposure with internal bioindicators of exposure (such as VTG expression). Periodic measurements of receptor activity or levels of known receptor agonists prior to sampling of fish are necessary in order to identify sites that have recurring high levels of contaminants such as natural steroidal estrogens, and to understand fluctuations in estrogenic levels and effects in fish.. Although, there is substantial variability in structure, most potent AhR ligands have high log Koc and log Kow partition coefficients, and as such might reasonably be expected to be found at higher concentration in sediments than in the water column. In this study, the receptor activity of sediments was not examined, and consequently there is a need to do so, to assess the ecological significance of the bioassay data. 


\section{Acknowledgments}

This study was approved and conducted under RMIT University Animal Ethics Committee Permit AEC 0702.

The research was primarily supported by Melbourne Water, but in part also by the Department of Primary Industries (Project \#08160 and 06889), the Australian Research Council (Discovery Grant \#DP0343410), and the Victorian Water Trust (Project \#33V-4000), with additional resources from the Centre for Aquatic Pollution, Identification and Management (CAPIM).

10 CAPIM is funded by The Victorian Science Agenda Investment Fund managed by the Department of Business and Innovation (DBI) (www.innovation.vic.gov.au) with partner funding contributed from Melbourne Water, Department of Primary Industries (Victoria), and Environment Protection Authority (Victoria).,. 


\section{References}

20 Angus RA, McNatt HB, Howell WM, Peoples SD (2001) Gonopodium development in normal male and 11-ketotestosterone-treated female mosquitofish (Gambusia affinis): A quantitative study using computer image analysis. Gen Comp Endocr 123:222-234.

Angus RA, Weaver S, Grizzle J, Watson R (2002) Reproductive characteristics of male mosquitofish (Gambusia affinis) inhabiting a small southeastern US river receiving treated domestic sewage effluent. Environ Toxicol Chem 21:1404-1409

Angus R, Stanko J, Jenkins RL, Douglas W (2005) Effects of 17 $\alpha$-ethynylestradiol on sexual development of male western mosquitofish (Gambusia affinis). Comp Biochem Phys C $140: 330-339$

Allinson G, Allinson M, Salzman S, Shiraishi F, Myers J, Theodoropoulos T, Hermon K, Wightwick A (2007) Hormones in treated sewage effluent. Final Report. A report prepared for the Victorian Water Trust. Department of Primary Industries, Queenscliff, Australia. 65pp. Available on-line: http://www.ourwater.vic.gov.au/programs/victorian-watertrust/publications Last accessed: 4 January 2010

Allinson G, Allinson M, Shiraishi F, Salzman SA, Myers JH, Hermon KM, Theodoropoulos T (2008) Androgenic activity of effluent from forty-five municipal waste water treatment plants in Victoria, Australia. Trans Ecol Environ 110:293-304

Allinson M, Shiraishi F, Nakajima D, Goto S, Allinson G (2011a) A pilot study of the water quality of the Yarra River, Victoria, Australia, using in vitro techniques. Bull Environ Contam Toxicol 87:591-598

40 Allinson M, Shiraishi F, Allinson G (2011b) A comparison of recombinant receptor-reporter gene bioassays and a total estrogen enzyme linked immunosorbant assay for the rapid screening of estrogenic activity in natural and waste waters. Bull Environ Contam Toxicol 86(5):461-464

Ayres RM, Pettigrove VJ, Hoffmann AA (2010) Low diversity and high levels of population genetic structuring in introduced eastern mosquitofish (Gambusia holbrooki) in the greater Melbourne region, Australia. Biol Invasions 12: 3727 - 3744 
den Besten PJ (1998) Concepts for the implementation of biomarkers in environmental monitoring. Mar Environ Res 46(1-5):253-256

Bisazza A, Marin G (1995) Sexual selection and sexual size dimorphism in the eastern mosquitofish Gambusia holbrooki (pisces poeciliidae). Ethol Ecol Evol 7:169-183

Batty J and Lim R (1999) Morphological and reproductive characteristics of male mosquitofish (Gambusia affinis holbrooki) inhabiting sewage-contaminated waters in New South Wales, Australia. Arch Environ Contam Toxicol 36: 301-307

Burkhardt-Holm P, Segner H, Burki R, Peter A, Schubert S, Suter M, Bormsuk ME (2008) Estrogenic endocrine disruption in Switzerland: An assessment of fish exposure and effects. Chimia 62:376-382

Degitz SJ, Holcombe GW, Kosian PA, Tietge JE, Durhan EJ, Ankley GT (2003) Comparing the effects of stage and duration of retinoic acid exposure on amphibian limb development: chronic exposure results in mortality, not limb malformations. Toxicol Sci 74:139-146

Doyle CJ, Lim RP (2002) The effect of $17 \beta$-estradiol on the gonopodial development and sexual activity of Gambusia holbrooki. Environ Toxicol Chem 21(12): 2719-2724

Dreze V, Monad G (2000) Effects of 4-nonylphenol on sex differentiation and puberty in mosquitofish (Gambusia holbrooki). Ecotoxicology 9: 93-103

Game C, Gagnon MM, Webb D, Lim R (2006) Endocrine disruption in male mosquitofish (Gambusia holbrooki)) inhabiting wetlands in Western Australia. Ecotoxicology 15: 665672

Gardiner D, Ndayibagira A, Grün F, Blumberg B (2003) Deformed frogs and environmental retinoids. Pure Appl Chem 75: 2263-2273

Hanson N (2009) Utility of biomarkers in fish for environmental monitoring. Integr Environ Assess Manage 5:180-181

Hilscherová K, Machala M, Kannan K, Blankenship AL, Giesy JP (2000) Cell bioassays for detection of aryl hydrocarbon (AhR) and estrogen receptor (ER) mediated activity in environmental samples. Environ Sci Pollut Res 7:159-171

Hou L, Xie Y, Ying G, Fang Z (2011) Developmental and reproductive characteristics of western mosquitofish (Gambusia affinis) exposed to paper mill effluent in the Dengcun River, Sihui, South China. Aquat Toxicol 103: 140-149 
Inoue D, Nakama K, Sawada K, Watanabe T, Takagi M, Sei K, Yang M, Hirotsuji J, Hu J, Nishikawa J, Nakanishi T, Ike M (2010) Contamination with retinoic acid receptor agonists in two rivers in the Kinki region of Japan. Water Res 44:2409-2418

Inoue D, Nakama K, Matsui H, Sei K, Michihiko Ike (2009) Detection of agonistic activities against five human nuclear receptors in river environments of Japan using a yeast twohybrid assay. Bull Environ Contam Toxicol 82:399-404

Janośek J, Hilscherová K, Bláha L, Holoubek I (2006) Environmental xenobiotics and nuclear receptors - Interactions, effects and in vitro assessment. Toxicol in Vitro 20:18-37

Janośek J, Beníšek M, Hilscherová K (2008) Disruption of retinoid transport, metabolism and signalling by environmental pollutants. Environ Int 34:898-913

JEA (2008) Draft manual for surveying exogenous endocrine disrupting chemicals (water, sediment, aquatic organisms). Japan Environment Agency, Water Quality Bureau, Water Quality Management Division, Tokyo, Japan. Available online (in Japanese): www.env.go.jp/chemi/end/manual/water.html Last Accessed 3 August 2009

Jobling S, Nolan M, Tyler CR, Brighty G, Stumpter JP (1998) Wildspread sexual disruption in wild fish. Environ Sci Technol 32: 2498-2506

Jugan ML, Oziol L, Bimbot M, Huteau V, Tamisier-Karolak S, Blondeau JP, Lévi Y(2009) In vitro assessment of thyroid and estrogenic endocrine disruptors in wastewater treatment plants, rivers and drinking water supplies in the greater Paris area (France). Sci Total Environ 407: 3579-3587

Kamata R, Shiraishi F, Nishikawa, J, Yonemoto J, Shiraishi H (2008) Screening and detection of the in vitro agonistic activity of the retinoic acid receptor. Toxicol in Vitro 22:10501061

100 Kamata R, Shiraishi F, Nakajima D, Takigami H, Shiraishi H (2009) Mono-hydroxylated polychlorinated biphenyls are potent aryl hydrocarbon receptor ligands in recombinant yeast cells. Toxicol in Vitro 23:736-743

Kelly MA, Reid AM, Quinn-Hosey KM, Fogarty AM, Roche JJ, Brougham CA (2010) Investigation of the estrogenic risk to feral male brown trout (Salmo trutta) in the Shannon International River Basin District of Ireland. Ecotoxicol Environ Safety 73:1658-1665 
Kinnberg K (2003) Evaluation of in vitro assays for determination of estrogenic activity in the environment (No. 43). Danish Environmental Protection Agency, Danish Ministry of the Environment

Kirby MF, Smith AJ, Rooke J, Neall P, Scott AP, Katsiadaki I (2007) Ethoxyresorufin-Odeethylase (EROD) and vitellogenin (VTG) in flounder (Platichthys flesus): System interaction, crosstalk and implications for monitoring. Aquat Toxicol 81 233-244

Lada M, Mattingly HT (2006) Identifying environmental conditions to promote species coexistence: an example with the native Barrens topminnow and invasive western mosquitofish. Biol. Invasions 8:719-725

115 Lavado R, Loyo-Rosales JE, Floyd E, Kolodziej EP, Snyder SA, Sedlak DL, Schlenk D (2009) Site-specific profiles of estrogenic activity in agricultural areas of California's inland waters. Environ Sci Technol 43:9110-9116

Leusch FL, De Jager C, Levi Y, Lim R, Puijker L, Sacher F, Tremblay LA, Wilson VS, Chapman HF (2010) Comparison of five in vitro bioassays to measure estrogenic activity in environmental waters. Environ Sci Technol 44: 3853-3860

Leusch FL, Chapman HF, Kay GW, Gooneratne, SR, Tremblay LA (2006) Anal fin morphology and gonadal histopathology in Mosquitofish (Gambusia holbrooki) exposed to treated municipal sewage effluent. Arch Environ Contam Toxicol 50: 562-574

Meffe GK (1992) Plasticity of life-history characters in eastern mosquitofish (Gambusia holbrooki: Poeciliidae) in response to thermal stress. Copeia 1:94-102

Miège C, Karolak S, Gabet V, Jugan M-L, Oziol L, Chevreuil M, Levi Y, Coquery M (2009) Evaluation of estrogenic disrupting potency in aquatic environments and urban wastewaters by combining chemical and biological analysis. Trends Anal Chem 28:186195

130 Miller CA (1999) A human aryl hydrocarbon receptor signalling pathway constructed in yeast displays additive responses to ligand mixtures. Toxicol Appl Pharmacol 160:297-303

Morgan DL, Gill HS, Maddern MG, Beatty SJ (2004) Distribution and impacts of introduced freshwater fishes in Western Australia. NZ J Mar Freshwat Res 38: 511 - 523 
Navas JM, Segner H (2000) Antiestrogenicity of $\beta$-naphthoflavone and PAHs in cultured rainbow trout hepatocytes: evidence for a role of the arylhydrocarbon receptor. Aquat Toixol 51: 79-92.

Nishikawa J-I, Saito K, Goto J, Dakeyama F, Matsuo M, Nishihara T (1999) New screening methods for chemicals with hormonal activities using interaction of nuclear hormone receptor with coactivator. Toxicol App Pharmacol 154:76-83

140 Norris A, Burgin S (2011) Answering questions on the impact of recycled water on wildlife using Gambusia holbrooki as a surrogate. Aust Zool 35: 1047-1052

Oh SM, Kim HR, Park HK, Choi K, Ryu J, Shin HS, Park J-S, Lee JS, Chung KH (2009) Identification of estrogen-like effects and biologically active compounds in river water using bioassays and chemical analysis. Sci Total Environ 407:5787-5794

145 Ogino Y, Katoh H, Yamada G (2004) Androgen dependent development of a modified anal fin, gonopodium, as a model to understand the mechanism of secondary sexual character experession in vertebrates. FEBS Letters 575: 119-126

Pyke GH (2005) A review of the biology of Gambusia affinis and G.holbrooki. Rev Fish Biol Fish 15: 339 - 365

150 Pyke GH (2008) Plaque minnow or mosquitofish: A review of the biology and impacts of introduced Gambusia species. Annu Rev Ecol Evol Syst 39:171-191

Rawson CA, Tremblay LA, Warne MStJ, Ying G, Kookana R, Laginestra E, Chapman JC, Lim RP (2009) Bioactivity of POPs and their effects in mosquitofish in Sydney Olympic Park, Australia. Sci Total Environ 407:3721-3730

155 Schilirò T, Pignata C, Rovere R, Fea E, Gilli G (2009) The endocrine disrupting activity of surface waters and of wastewater treatment plant effluents in relation to chlorination. Chemosphere 75:335-340

Shiraishi F, Shiraishi H, Nishikawa J, Nishihara T, Morita M (2000) Development of a simple operational estrogenicity assay system using the yeast two-hybrid system. Kankyo Kagaku 10: 57-64 (in Japanese)

Shiraishi F, Okumura T, Nomachi M, Serizawa S, Nishikawa J, Edmonds JS, Shiraishi H, Morita M (2003) Estrogenic and thyroid hormone activity of a series of hydroxylpolychlorinated biphenyls. Chemosphere 52: 33-42 
Shue M-F, Chen F-A, Chen TC (2010) Total estrogenic activity and nonylphenol concentration in the Donggang River, Taiwan. Environ Monit Assess 168:91-101

Sone K, Hinago M, Itamoto M, Katsu Y, Watanabe H, Urushitani H, Tooi O, Guillette LJ, Iguchi T (2005) Effects of an androgen growth promoter $17 \beta$-trenbolone on masculinization of Mosquitofish (Gambusia affinis affinis). Gen Comp Endocr 143: 151160

170 Streck G (2009) Chemical and biological analysis of estrogenic, progestagenic and androgenic steroids in the environment. TrAC Trends Anal Chem 28: 635-652

JP Sumpter (2008) The ecotoxicology of hormonally active micropollutants. Water Sci Technol 57(1): 125-130

Sumpter J, Johnson A (2008) 10th anniversary perspective: Reflections on endocrine disruption in the aquatic environment; from known knowns to unknown unknowns (and many things in between). J Environ Monitor 10: 1476-1485

Toft G, Edwards TM, Baatrup E, Guillette LJ (2003) Disturbed sexual characteristics in male mosquitofish (Gambusia holbrooki) from a lake contaminated with endocrine disruptors. Environ Health Perspect 111:695-701

180 Van der Oost R, Beyer, J, Vermeulen N P E (2003) Fish bioaccumulation and biomarkers in environmental risk assessment: a review. Environ Toxicol Phar 13:57-149

Wang L, Ying G-G, Zhao J-L, Liu S, Yang B, Zhou L-J, Tao R, Su H-C (2011) Assessing estrogenic activity in surface water and sediment of the Liao River system in northeast China using combined chemical and biological tools. Environ Poll 159:148-156

185 Winkler P (1979) Thermal preference of Gambusia affinis affinis as determined under field and laboratory conditions. Copeia 1979: 60-64

Xie Y, Fang Z, Hou L, Ying G (2010) Altered development and reproduction in western mosquitofish (Gambusia affinis) found in the Hanxi River, southern China. Environ Toxicol Chem 29: 2607-2615

190 Xiong KM, Peterson RE, Heideman W (2008) Aryl hydrocarbon receptor-mediated downregulation of sox9b causes jaw malformation in zebrafish embryos. Mol Pharmacol 74: $1544-1553$ 
Zulian E, Bisazza A, Marin G (1993) Determinants of size in male eastern mosquitofish (Gambusia holbrooki): Inheritance and plasticity of a sexual selected character. B Zool 195 $60: 317-322$

Zulian E, Bisazza A, Marin G (1995). Variations in male body size in natural populations of Gambusia holbrooki. Ethol Ecol Evol 7:1-10 
Figure 1 Adult male mosquitofish gonopodium. (a) Adult male mosquitofish with fully developed gonopodium; (b) gonopodium showing elongated rays 3, 4 and 5; (c) fully developed gonopodium tip showing hooks and serrae.

210

Figure 2 Approximate location of sampling sites in and around the city of Port Philip Bay (PPB) and Melbourne (M), in Victoria, Australia 
215 Figure 1
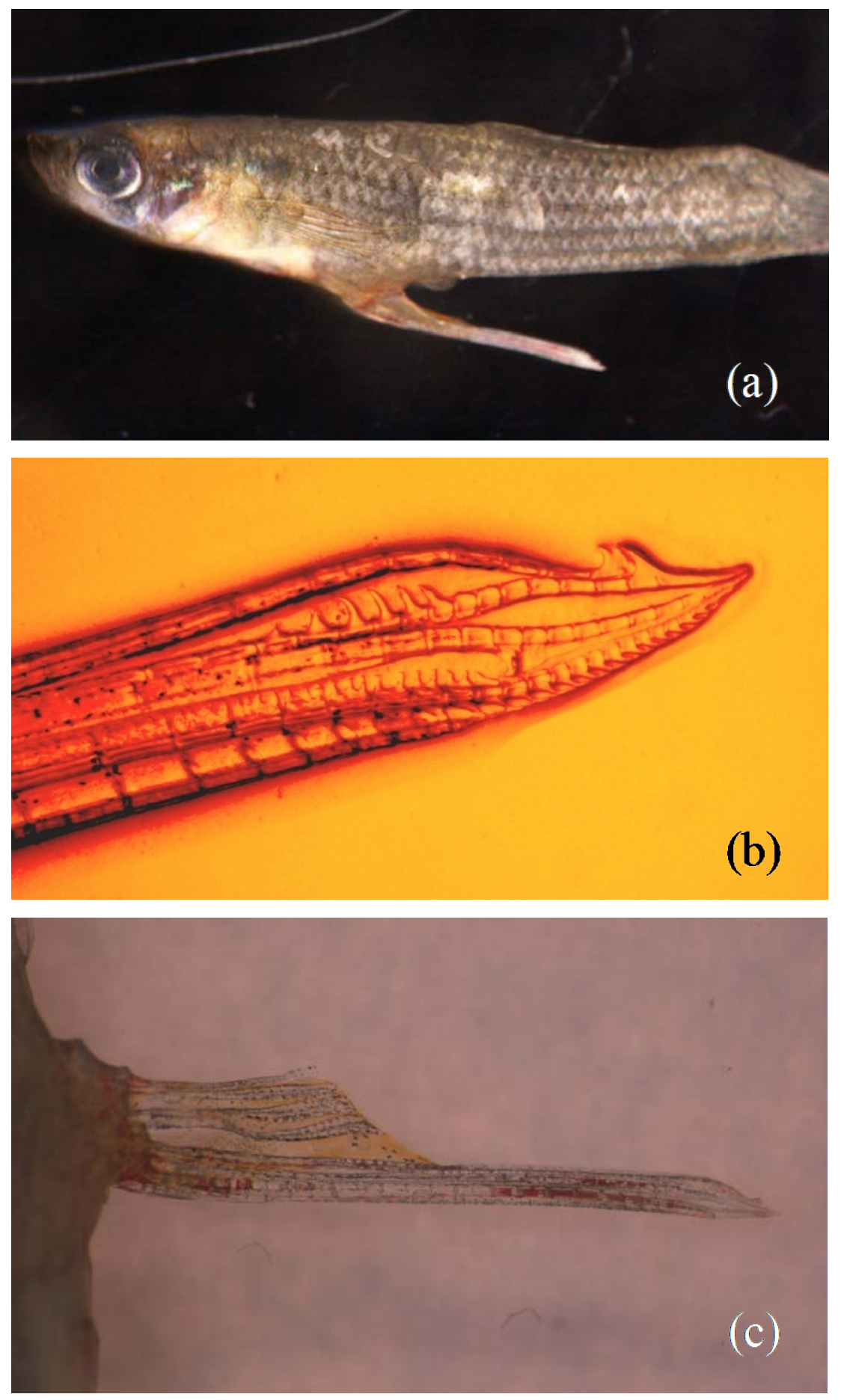

220 
$230 \quad$ Figure 2

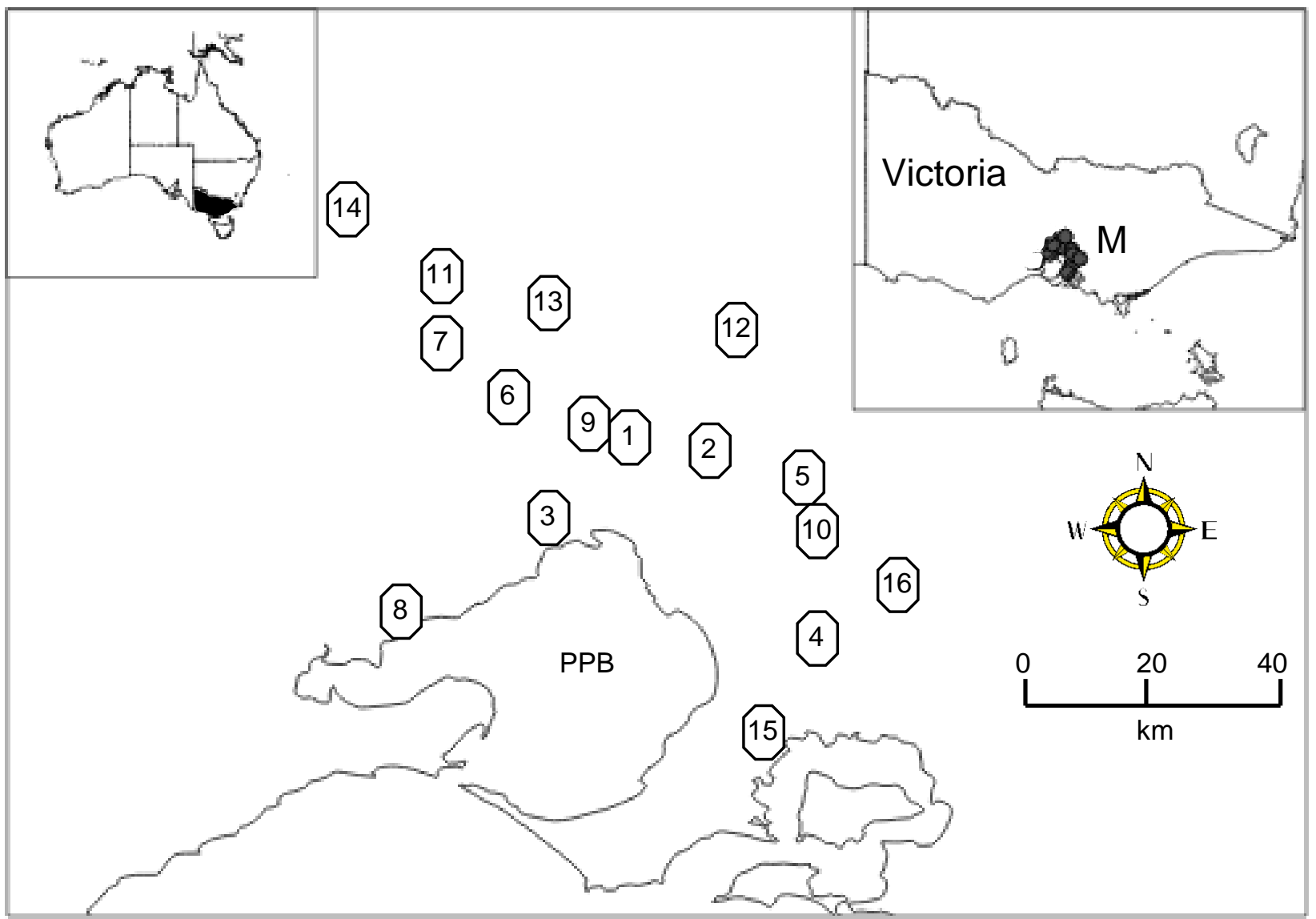


List of Tables

235 Table 1 Summary of male mosquitofish morphometric data

Table 2 Summary of water quality data

240

Table 3 A comparison of the estrogen agonist activity of Victorian rivers with that reported elsewhere in Australia and internationally (post-2005 data only). EEQ, estradiol equivalents; *, estimated from authors' manuscript figures; N.D., not detected (including reported measures such as 'trace,' below limits of reporting ( $<\mathrm{LOR})$, and below limits of determination or detection $(<\mathrm{LOD})$, where these values are not clearly defined by authors 
Table 1

\begin{tabular}{|c|c|c|c|c|c|c|c|c|c|c|c|c|c|}
\hline \multirow{2}{*}{$\begin{array}{l}\text { Group } \\
\text { Ref }\end{array}$} & \multirow{2}{*}{$\begin{array}{c}\text { Site } \\
\# \\
10\end{array}$} & \multirow{2}{*}{$\begin{array}{l}\text { Description } \\
\text { Lake }\end{array}$} & \multirow{2}{*}{$\begin{array}{c}\mathrm{n} \\
15\end{array}$} & \multicolumn{2}{|c|}{$\begin{array}{c}\text { Standard length } \\
(\mathrm{mm})\end{array}$} & \multicolumn{2}{|c|}{$\begin{array}{c}\text { Gonopodium length } \\
(\mathrm{mm})\end{array}$} & \multicolumn{2}{|c|}{ GL/BL ratio } & \multicolumn{2}{|c|}{ R4:6 ratio } & \multicolumn{2}{|c|}{$\begin{array}{c}\text { Mass } \\
(\mathrm{g})\end{array}$} \\
\hline & & & & $17.88^{\mathrm{ac}}$ & \pm 0.44 & 6.11 & \pm 0.13 & $0.35^{\mathrm{ad}}$ & \pm 0.01 & $2.51^{a}$ & \pm 0.07 & $0.101^{\mathrm{b}}$ & \pm 0.007 \\
\hline & 9 & Lake & 16 & $17.88^{\mathrm{ac}}$ & \pm 0.33 & 6.45 & \pm 0.11 & $0.36^{\text {acd }}$ & \pm 0.01 & $2.71^{a}$ & \pm 0.06 & $0.105^{b}$ & \pm 0.006 \\
\hline & 12 & Lake & 15 & $17.87 \mathrm{ac}$ & \pm 0.48 & 6.67 & \pm 0.17 & 0.37 acd & \pm 0.01 & $2.71^{a}$ & \pm 0.05 & $0.107^{b}$ & \pm 0.009 \\
\hline & 11 & Lake & 15 & $21.47^{\mathrm{b}}$ & \pm 0.26 & 7.61 & \pm 0.11 & $0.35^{\text {bd }}$ & \pm 0.00 & $2.65^{a}$ & \pm 0.03 & $0.160^{\mathrm{a}}$ & \pm 0.009 \\
\hline \multirow[t]{5}{*}{ Rural } & 13 & Creek & 14 & $17.72^{\mathrm{ac}}$ & \pm 0.34 & 6.41 & \pm 0.13 & $0.36^{\mathrm{ad}}$ & \pm 0.00 & $2.60^{a}$ & \pm 0.04 & $0.113^{b}$ & \pm 0.007 \\
\hline & 14 & River & 17 & $18.85^{\mathrm{ac}}$ & \pm 0.30 & 6.78 & \pm 0.14 & $0.36^{\mathrm{ad}}$ & \pm 0.01 & $2.73^{a}$ & \pm 0.08 & $0.118^{a}$ & \pm 0.008 \\
\hline & ${ }^{*} 16$ & Lake & 15 & $18.37^{a c}$ & \pm 0.36 & 7.11 & \pm 0.14 & $0.39^{a c}$ & \pm 0.00 & $2.78^{a}$ & \pm 0.05 & $0.118^{\mathrm{a}}$ & \pm 0.007 \\
\hline & 15 & Creek & 14 & $19.36^{\mathrm{a}}$ & \pm 0.27 & 6.98 & \pm 0.09 & $0.36^{\mathrm{ad}}$ & \pm 0.00 & $2.55^{a}$ & \pm 0.05 & $0.124^{\mathrm{b}}$ & \pm 0.006 \\
\hline & $* 4$ & Stormwater drain & 16 & $17.22^{\mathrm{ac}}$ & \pm 0.24 & 6.55 & \pm 0.10 & $0.38^{\text {acd }}$ & \pm 0.01 & $2.67^{\mathrm{a}}$ & \pm 0.05 & $0.086^{\mathrm{b}}$ & \pm 0.005 \\
\hline \multirow[t]{3}{*}{ Urban } & $* 1$ & Creek & 15 & $16.27^{c}$ & \pm 0.32 & 6.50 & \pm 0.12 & $0.40^{\mathrm{ac}}$ & \pm 0.01 & $2.72^{a}$ & \pm 0.05 & $0.078^{\mathrm{b}}$ & \pm 0.004 \\
\hline & 2 & Wetland & 10 & $18.75^{\mathrm{a}}$ & \pm 0.44 & 6.48 & \pm 0.15 & $0.35^{\mathrm{bd}}$ & \pm 0.00 & $2.73^{a}$ & \pm 0.06 & $0.124^{\mathrm{a}}$ & \pm 0.006 \\
\hline & $* 3$ & Creek & 14 & $18.93^{a}$ & \pm 0.41 & 6.55 & \pm 0.16 & $0.35^{\mathrm{bd}}$ & \pm 0.01 & $2.53^{a}$ & \pm 0.08 & $0.155^{\mathrm{a}}$ & \pm 0.007 \\
\hline \multirow[t]{4}{*}{ WWTP } & 5 & Creek & 18 & $17.06^{\mathrm{ac}}$ & \pm 0.5 & 6.57 & \pm 0.11 & $0.39^{a}$ & \pm 0.01 & $2.86^{\mathrm{b}}$ & \pm 0.06 & $0.090^{\mathrm{b}}$ & \pm 0.008 \\
\hline & 6 & Creek & 15 & $16.93^{\mathrm{ac}}$ & \pm 0.40 & 6.27 & \pm 0.17 & 0.37 acd & \pm 0.01 & $2.79^{a}$ & \pm 0.07 & $0.093^{b}$ & \pm 0.007 \\
\hline & 7 & Creek & 14 & $17.33^{\mathrm{ac}}$ & \pm 0.37 & 6.31 & \pm 0.12 & $0.34^{\text {acd }}$ & \pm 0.02 & $2.68^{\mathrm{a}}$ & \pm 0.06 & $0.087^{b}$ & \pm 0.006 \\
\hline & 8 & Drain & 15 & $18.67^{a}$ & \pm 0.35 & 6.92 & \pm 0.13 & $0.37^{a}$ & \pm 0.00 & $2.64^{\mathrm{a}}$ & \pm 0.05 & $0.117^{b}$ & \pm 0.006 \\
\hline
\end{tabular}

* includes sites that could be classified as either rural or urban (sites 4 and 16) and urban or industrial (sites 1 and 3); n, number of fish in sample;

GL, gonapodium length; BL, body length; R4:6, rap 4/6 ratio; Ref, reference site; WWTP, wastewater treatment plant influenced sites; Means not sharing the same letters are significantly different from each other 
Table 2

\begin{tabular}{|c|c|c|c|c|c|c|c|c|c|c|c|}
\hline \multirow{3}{*}{$\underset{*}{\text { Group }}$} & \multirow[t]{3}{*}{ Site \# } & \multirow{3}{*}{$\begin{array}{l}\text { Temp } \\
\left({ }^{\circ} \mathrm{C}\right)\end{array}$} & & \multirow{3}{*}{$\begin{array}{c}\text { EC } \\
(\mu \mathrm{S} / \mathrm{cm})\end{array}$} & \multirow{3}{*}{$\begin{array}{c}\text { TOC } \\
(\mathrm{mg} / \mathrm{L})\end{array}$} & \multicolumn{6}{|c|}{ Receptor activity } \\
\hline & & & & & & \multirow[t]{2}{*}{ ES } & $\mathrm{hER} \alpha$ & $\operatorname{medER} \alpha$ & RAR & TR & AhR \\
\hline & & & & & & & EEQ & & a-t-RA EQ & T3 EQ & $\beta N F$ EQ \\
\hline & & & & & & & & & (ng/L) & & \\
\hline Ref & 10 & 21.7 & 7.1 & 940 & $\mathrm{n} / \mathrm{a}$ & 0.6 & 1.7 & 1.6 & 5.2 & $<14$ & 26 \\
\hline$"$ & 9 & 20.6 & 7.8 & 2910 & 13.8 & 0.5 & $<0.1$ & $<0.4$ & $<0.4$ & $<14$ & 7 \\
\hline$"$ & 12 & 18.7 & 6.0 & 80 & 25.7 & 0.2 & $<0.1$ & $<0.4$ & 0.9 & $<14$ & 11 \\
\hline$"$ & 11 & 25.0 & 6.5 & 160 & 7.2 & 0.1 & $<0.1$ & $<0.4$ & $<0.4$ & $<14$ & 19 \\
\hline Rural & 13 & 20.3 & 9.1 & 2000 & 12.2 & 0.2 & $<0.1$ & $<0.4$ & $<0.4$ & $<14$ & 8 \\
\hline$"$ & 14 & 25.1 & 9.0 & 1250 & 14.7 & 0.7 & 0.3 & $<0.4$ & $<0.4$ & $<14$ & 16 \\
\hline$"$ & 16 & 21.4 & 7.6 & 160 & 5.9 & 0.8 & $<0.1$ & $<0.4$ & 0.9 & $<14$ & 14 \\
\hline$"$ & 15 & 18.0 & 6.9 & 620 & 8.2 & 1.0 & 0.1 & $<0.4$ & 0.8 & $<14$ & 12 \\
\hline$"$ & 4 & 24.5 & 6.3 & 610 & 19.7 & 1.6 & 1.4 & 1.1 & 4.5 & $<14$ & 180 \\
\hline Urban & 1 & 18.8 & 7.7 & 1920 & $\mathrm{n} / \mathrm{a}$ & 0.6 & $<0.1$ & $<0.4$ & $<0.4$ & $<14$ & 27 \\
\hline$"$ & 2 & 18.6 & 7.5 & 2370 & 8.9 & 1.0 & $<0.1$ & 0.8 & 0.5 & $<14$ & 14 \\
\hline$"$ & 3 & 20.0 & 7.7 & 3580 & 11.9 & 0.1 & $<0.1$ & $<0.4$ & $<0.4$ & $<14$ & 35 \\
\hline WWTP & 5 & 19.4 & 6.8 & 717 & 9.5 & 1.5 & 0.3 & $<0.4$ & 0.4 & 43 & 130 \\
\hline$"$ & 6 & 19.3 & 8.6 & 3050 & 8.9 & 1.7 & 0.9 & $<0.4$ & 2.2 & $<14$ & 31 \\
\hline$"$ & 7 & 15.3 & 6.8 & 813 & 8.8 & 12.5 & 12.0 & 11.0 & 8.1 & $<14$ & 19 \\
\hline$"$ & 8 & 19.0 & 8.0 & 519 & 42.8 & 1.2 & 0.6 & $<0.4$ & $<0.4$ & 43 & 24 \\
\hline
\end{tabular}

$255 *$ includes sites that could be classified as either rural or urban (sites 4 and 16) and urban or industrial (sites 1 and 3); n, number of fish in sample 
Table 3

\begin{tabular}{|c|c|c|c|c|c|}
\hline \multirow[t]{2}{*}{ Location } & \multirow[t]{2}{*}{ Assay } & \multicolumn{3}{|c|}{ Estrogenic activity } & \multirow[t]{2}{*}{ Reference } \\
\hline & & u/s WWTP & $\mathrm{d} / \mathrm{s}$ WWTP & $\begin{array}{c}\text { Other } \\
\text { (ng/L EEQ) }\end{array}$ & \\
\hline China & YES & & & $0.2-78.8$ & Wang et al, 2011 \\
\hline France & $\begin{array}{l}\text { MELN } \\
\text { MELN }\end{array}$ & $\begin{array}{c}<1.2 \\
<0.3-2.8\end{array}$ & $\leq 2.5$ & & $\begin{array}{l}\text { Jugan et al, } 2009 \\
\text { Miège et al, } 2009\end{array}$ \\
\hline Ireland & YES & $0.5-2.7$ & $0.9-1.5$ & & Kelly et al. 2010 \\
\hline Italy & E-screen & $5.0 \pm 6.1$ & & & Schilirò et al, 2009 \\
\hline Japan & $\mathrm{Y} 2 \mathrm{H}$ & & & & \\
\hline South Korea & E-screen & 0.08 & $0.03-0.7$ & $0.1-0.3$ & Oh et al, 2009 \\
\hline Taiwan & MVLN & & & $0.3-4.4$ & Shue et al, 2010 \\
\hline USA & & & Australia & $<0.15-242$ & Lavado et al, 2009 \\
\hline $\begin{array}{l}\text { Queensland } \\
\text { Vic } \\
\text { Victoria }\end{array}$ & $\begin{array}{l}\text { E-screen } \\
\text { Y2H } \\
\text { Y2H }\end{array}$ & & $<0.3-11$ & $\begin{array}{c}<0.2-0.95^{*} \\
<0.5 \\
<0.3-1.6\end{array}$ & $\begin{array}{l}\text { Leusch et al, } 2010 \\
\text { Allinson et al, 2011a } \\
\text { This study }\end{array}$ \\
\hline
\end{tabular}

u/s WWTP, upstream of a WWTP discharge; d/s WWTP, downstream of a WWTP discharge; Other, 260 agricultural or urban site, or no data on nature of site; MELN, assay using transformed MCF-7 human breast cancer cells; Y2H, yeast two-hybrid assay using the recombinant yeast Saccharomyces cerevisiae Y190; E-screen, assay with human estrogens receptor-positive MCF-7 BUS breast cancer cells; * estimated from author figures 